\title{
InfoNorth
}

\section{Effects of the White River Ash Event and Climate Change on Aquatic}

\section{Ecosystems in the Southwest Yukon}

\author{
by Joan Bunbury
}

\section{INTRODUCTION}

$\mathrm{F}$ RESHWATER LAKE ENVIRONMENTS ARE AFFECTED by disturbances on several scales that influence the composition of biological communities. A volcanic eruption is an abrupt and severe disturbance, and evidence of its impact is seen in lake sediments and soils as a layer of ash. These volcanic deposits affect aquatic ecosystems in lakes: large volumes of tephra can literally smother organisms living at the sediment-water interface (Edmondson, 1984), though the thinner layers of ash deposited farther from the source may have more subtle impacts. A less catastrophic, more gradual disturbance affecting aquatic ecosystems is climate change. Variations in temperature and precipitation over time indirectly influence the aquatic environment and have the potential to alter species composition and abundance (Rouse et al., 1997).

The White River Ash event was the eruption of a stratovolcano (Mount Churchill, Alaska) in the St. Elias Mountains $25 \mathrm{~km}$ west of the Yukon border. This massive explosion deposited an enormous volume of tephra over the southern Yukon 1147 years BP (Clague et al., 1995; Robinson, 2001; West and Donaldson, 2002). An ash layer ranging from $1 \mathrm{~mm}$ to $.5 \mathrm{~m}$ in thickness has been observed in lake sediments. Where this layer is thicker, the event must have been catastrophic for the aquatic ecosystem.

Although we cannot directly measure the aquatic ecosystem that existed in the past, we can infer what it was like through the analysis of subfossil organisms and sediment parameters that have been preserved in lake sediments (Birks and Birks, 1980).

This research will use ostracodes and chironomids, two widely used biological proxies, to reconstruct environmental change (Griffiths and Holmes, 2000; Porinchu and MacDonald, 2003). Ostracodes are small, bivalved crustaceans with a shell that preserves well in lake sediments. Chironomids are the larval stage of non-biting midges, the head capsule of which is made of chitin and is also well preserved in lake sediments. Both of these organisms live at the sediment-water interface, consume organic detritus, and have parts that fossilize and can be identified to genus, or in many instances, to species. The ecological requirements of individual species are then used to infer the type

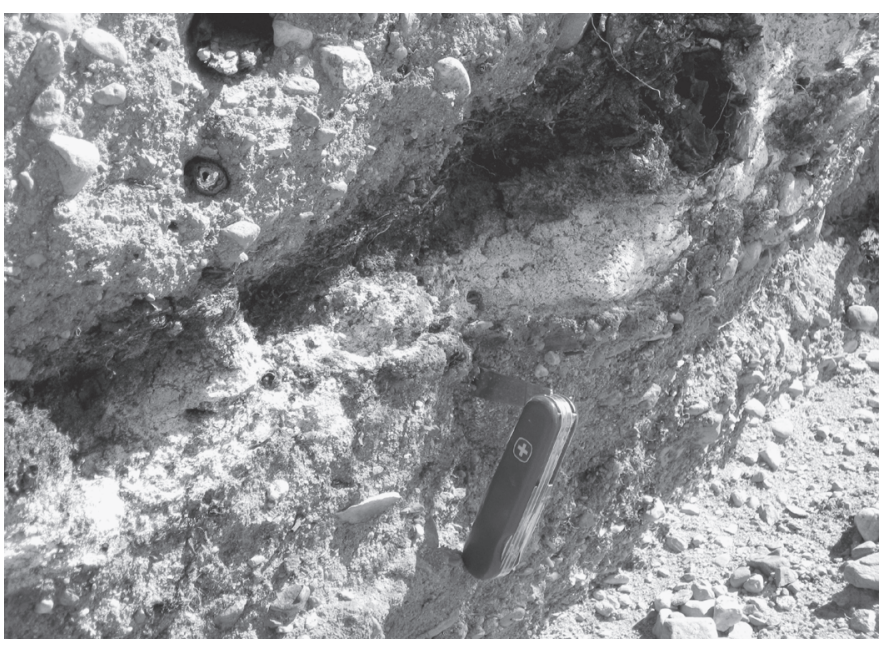

Soil section along the Aishihik Road, showing a layer of White River Ash (just above knife) covered by soil. (Photo: K. Gajewski)

of environment in which the ostracode and chironomid community once lived.

Two sediment parameters that represent past aquatic production are organic content and biogenic silica content. Organic matter found in lake sediments, which is either transported to the lake from the surrounding basin or produced within the lake, is a good measure of total ecosystem production (Delcourt and Delcourt, 1991). In freshwater environments, biogenic silica comes primarily from diatoms (unicellular algae; Wetzel, 2001), and an increase in its concentration suggests greater primary production. From a paleolimnological perspective, these sediment parameters represent the base of the food web, whereas ostracodes and chironomids are consumers that rely on primary production as a food source. Therefore, evidence of both primary producers and consumers is available in lake sediments to provide information about the past aquatic ecosystem.

My research, focused around understanding ecosystem response to two different stressors, has these goals: 1) to assess the impact that the White River ash had on aquatic ecosystems in the southwest Yukon; 2) to determine how aquatic ecosystems have responded to climate change over 


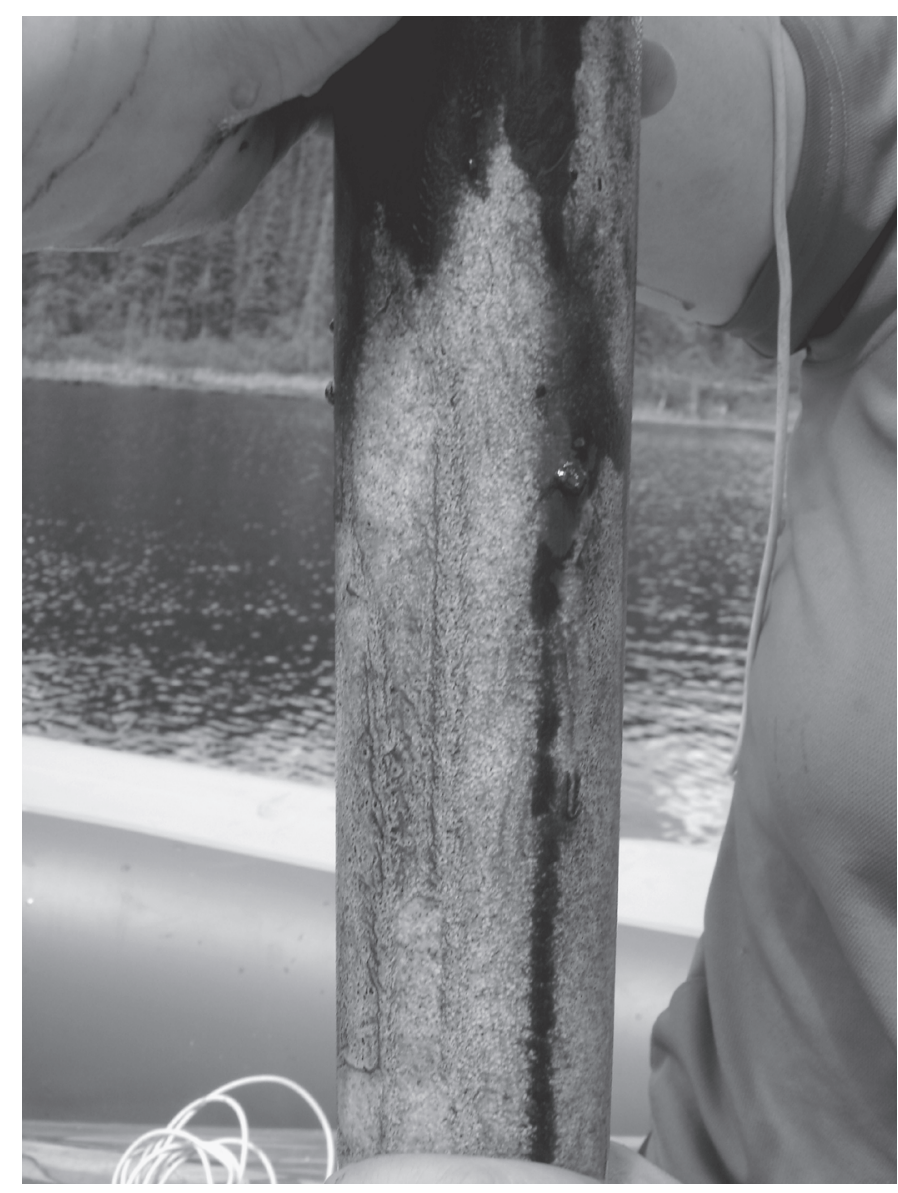

White River Ash in a lake sediment core from Donjek Kettle. (Photo: B. O’Neil)

the past 2000 years in the southwest Yukon; and 3) more generally, to infer whether aquatic ecosystems in the southwest Yukon respond in a similar manner to different environmental stressors, particularly the impact of the White River Ash event and climate change.

\section{METHODS}

This is a paleolimnological study that will use a highresolution multi-proxy (e.g., ostracodes, chironomids, sediment organic content, and biogenic silica content) approach to measure the impacts of the White River tephra on aquatic ecosystems and to evaluate climatic changes over the past two centuries. Multi-proxy analyses are critical to separating the effects of the different stresses on these systems.

Lake sediment cores have been collected from four sites in the southwest Yukon at different distances from the volcanic source. Lead-210 dating is being used to date the uppermost sediment layers ( $\sim 150$ years $)$ in the cores, and radiocarbon dating to develop a chronology for the remainder of the cores. These two dating approaches can be combined to determine sediment accumulation rates and assign ages to the sediment layers. This age assignment is

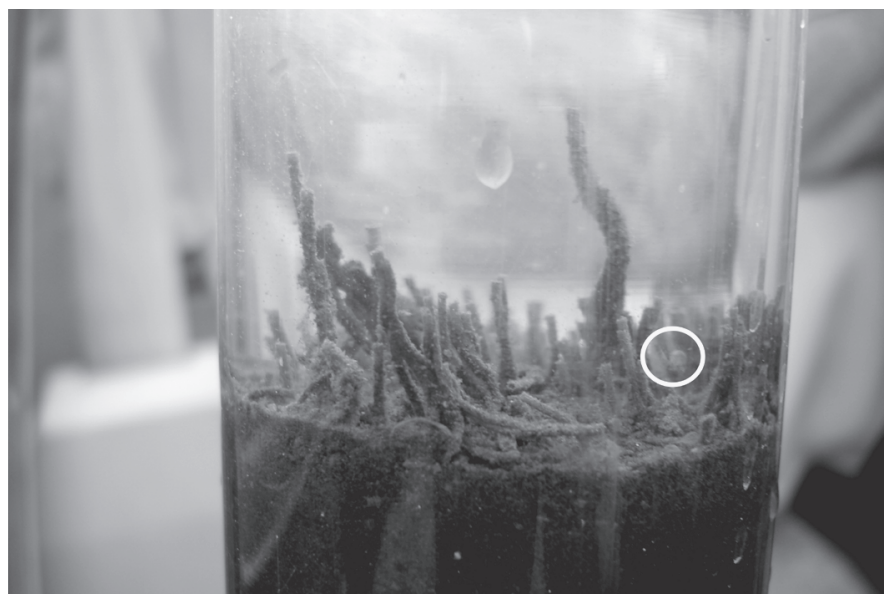

Sediment-water interface of a core from Donjek Kettle. A live chironomid is circled on the image. (Photo: B. O'Neil)

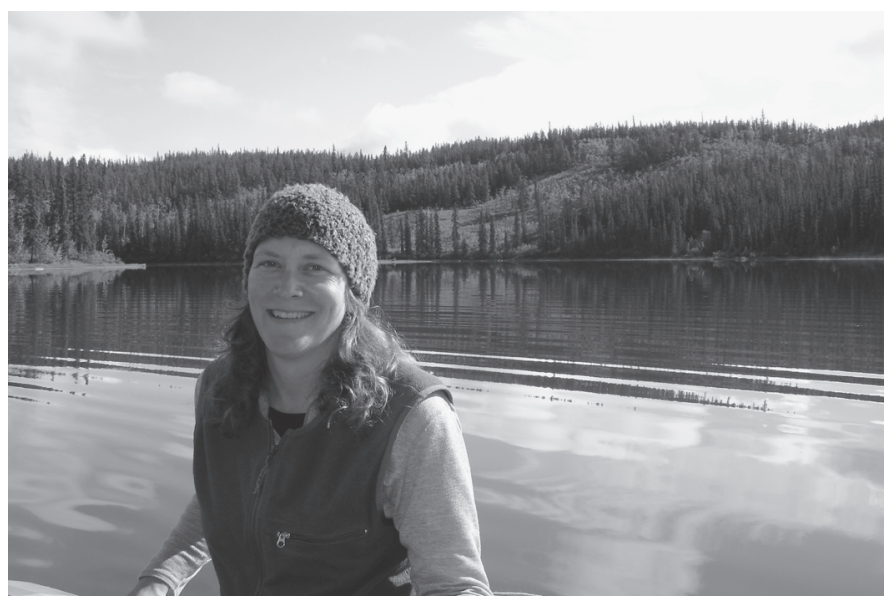

Joan Bunbury on a Yukon lake. (Photo: B. O'Neil)

essential to establish how long it took for the ecosystem to return to similar conditions that existed prior to the volcanic eruption.

Sediment cores are being subsampled at high resolution (i.e., $0.25-0.5 \mathrm{~cm}$ increments) for ostracodes, chironomids, and sediment parameters. Ostracode and chironomid subfossils are being identified from above and below the ash layer at the different sites to quantify both changes in the population and the trophic status of the lakes before and after the event. Standard methods are used to extract the fossils from the sediment (Smol et al., 2001) and the organisms are identified at a microscope.

The paleoclimate inferences developed from these fossil records will be compared to the recent Mount Logan ice core record (Fisher et al., 2008) and other lake sediment records in the region (Anderson et al., 2005) to distinguish climate change from other factors that cause ecosystem change. By quantifying changes over time in the ostracode and chironomid assemblages and the sediment parameters and evaluating the statistical significance of those changes, we can measure the impact of the tephra (Lotter and Birks, 1993; Lotter et al., 1995). The analysis will aid in 
reconstructing the effects of the White River Ash event and climate change over the last 2000 years on freshwater ecology in the southwest Yukon.

\section{SIGNIFICANCE}

An important question in ecology is how ecosystems respond to and recover from different environmental stressors, which include both extreme events such as volcanic eruptions and environmental fluctuations such as climate change. Ecological studies generally focus only on short-term scales (i.e., 10-20 years), whereas paleolimnological approaches can assess the response and recovery of aquatic ecosystems over longer time scales (i.e., hundreds to thousands of years). With such approaches, therefore, we can better understand how these different environmental stressors affected lakes in the region. This research will increase our knowledge of how aquatic ecosystems respond to different environmental stressors and how long they take to recover, as well as contribute to the prediction of climate change impacts in northern regions.

\section{ACKNOWLEDGEMENTS}

I am very honoured to be the recipient of the 2008 Jennifer Robinson Memorial Scholarship sponsored by the Arctic Institute of North America. Other funding sources that made this research possible include the Yukon Geological Survey, the Northern Research Institute (Yukon College) Research Fellowship Program, the Natural Sciences and Engineering Research Council of Canada, the Northern Scientific Training Program of the Department of Indian and Northern Affairs, the Canadian Northern Studies Trust Scholarship through the Association of Canadian Universities for Northern Studies Awards Program, and the University of Ottawa. I would also like to thank J. Bond at the Yukon Geological Survey and C. Sawicki at the Northern Research Institute (Yukon College) for their partnership in my NSERC Northern Internship that enabled me to experience living in the North. My sincerest thanks go to Andy Williams and the staff of Kluane Lake Research Station for providing much support (logistic and otherwise) over the years; to Peter Johnson, for introducing me to the Yukon; and to my supervisor, Konrad Gajewski, for his encouragement, support, and realistic attitude throughout this research project. I would also like to acknowledge the Champagne-Aishihik First Nation, the Kluane First Nation, and the White River First Nation for allowing access to their traditional territories for the purposes of this research.

\section{REFERENCES}

ANDERSON, L., ABBOTT, M.B., FINNEY, B.P., and BURNS, S.J. 2005. Regional atmospheric circulation change in the North Pacific during the Holocene inferred from lacustrine carbonate oxygen isotopes, Yukon Territory, Canada. Quaternary Research $64: 21-35$.
BIRKS, H.J.B., and BIRKS, H.H.1980. Quaternary palaeoecology. London: Edward Arnold (Publishers) Limited.

CLAGUE, J.J., EVANS, S.G., RAMPTON, V.N., and WOODSWORTH, G.J. 1995. Improved age estimates for the White River and Bridge River tephras, western Canada. Canadian Journal of Earth Sciences 32:1172-1179.

DELCOURT, H.R., and DELCOURT, P.A. 1991. Quaternary ecology: A paleoecological perspective. New York: Chapman $\&$ Hall.

EDMONDSON, W.T. 1984. Volcanic ash in lakes. The Northwest Environmental Journal 1:139-150.

FISHER, D., OSTERBERG, E., DYKE, A., DAHL-JENSEN, D., DEMUTH, M., ZDANOWICZ, C., BOURGEOIS, J., KOERNER, R.M., MAYEWKSI, P., WAKE, C., KREUTZ, K., STEIG, E., ZHENG, J., YALCIN, K., GOTO-AZUMA, K., LUCKMAN, B., and RUPPER, S. 2008. The Mt. Logan Holocene-Lake Wisconsinan isotope record: Tropical PacificYukon connections. The Holocene 18:667-677.

GRIFFITHS, H.I., and HOLMES, J.A. 2000. Non-marine ostracods and Quaternary paleoenvironments. Technical Guide No. 8. London: Quaternary Research Association.

LOTTER, A.F., and BIRKS, H.J.B. 1993. The impact of the Laacher See Tephra on terrestrial and aquatic ecosystems in the Black Forest, southern Germany. Journal of Quaternary Science 8:263-276.

LOTTER, A.F., BIRKS, H.J.B., and ZOLITSCHKA, B. 1995. Late-glacial pollen and diatom changes in response to two different environmental perturbations: Volcanic eruption and Younger Dryas cooling. Journal of Paleolimnology 14:23-47.

PORINCHU, D.F., and MACDONALD, G.M. 2003. The use and application of freshwater midges (Chironomidae: Insecta: Diptera) in geographical research. Progress in Physical Geography 27:378-422.

ROBINSON, S.D. 2001. Extending the Late Holocene White River Ash distribution, northwestern Canada. Arctic 54:157-161.

ROUSE, W.R., DOUGLAS, M.S.V., HECKY, R.E., HERSHEY, A.E., KLING, G.W., LESACK, L., MARSH, P., McDONALD, M., NICHOLSON, B., ROULET, N.T., and SMOL, J.P. 1997. Effects of climate change on the freshwaters of Arctic and Subarctic North America. Hydrological Processes 11:873-902.

SMOL, J.P., BIRKS, H.J.B., and LAST, W.M. 2001. Tracking environmental change using lake sediments. Developments in Paleoenvironmental Research Series, Vols. 1 -4. Boston: Kluwer Academic Publishers.

WEST, K.D., and DONALDSON, J.A. 2002. Resedimentation of the late Holocene White River tephra, Yukon Territory and Alaska. In: Emond, D.S., Weston, L.H., and Lewis, L.L., eds. Yukon Exploration and Geology 2001. Whitehorse: Exploration and Geological Services Division, Yukon Region, Indian and Northern Affairs Canada. 239-247.

WETZEL, R.G. 2001. Limnology: Lake and river ecosystems. New York: Academic Press.

Joan Bunbury, a doctoral student in the Department of Geography, University of Ottawa, is the recipient of the Jennifer Robinson Memorial Scholarship for 2008. 